OPEN ACCESS

Edited by:

Bradley J. Bergstrom, Valdosta State University,

United States

Reviewed by:

Stefania Ondei,

University of Tasmania, Australia

Peter McDonald

Northern Territory Government,

Australia

*Correspondence:

Cara E. Penton

cara.penton1@gmail.com

Specialty section:

This article was submitted to

Conservation and Restoration

Ecology,

a section of the journal

Frontiers in Ecology and Evolution

Received: 11 July 2021 Accepted: 13 October 2021 Published: 02 November 2021

Citation:

Penton CE, Davies HF, Radford IJ,

Woolley $L-A$, Rangers $T L$ and Murphy BP (2021) A Hollow Argument: Understory Vegetation and Disturbance Determine Abundance of Hollow-Dependent Mammals in an Australian Tropical Savanna. Front. Ecol. Evol. 9:739550. doi: $10.3389 /$ fevo.2021.739550

\section{A Hollow Argument: Understory Vegetation and Disturbance Determine Abundance of Hollow-Dependent Mammals in an Australian Tropical Savanna}

\author{
Cara E. Penton ${ }^{*}$, Hugh F. Davies ${ }^{1}$, lan J. Radford ${ }^{2}$, Leigh-Ann Woolley ${ }^{3}$, \\ Tiwi Land Rangers ${ }^{4}$ and Brett P. Murphy ${ }^{1}$ \\ 'Research Institute for the Environment and Livelihoods, Charles Darwin University, Darwin, NT, Australia, ${ }^{2}$ Department \\ of Biodiversity, Conservation and Attractions, Kununurra, WA, Australia, ${ }^{3}$ WWF-Australia, Broome, WA, Australia, ${ }^{4}$ Tiwi \\ Resources Pty., Ltd., Darwin, NT, Australia
}

Native mammals are suffering widespread and ongoing population declines across northern Australia. These declines are likely driven by multiple, interacting factors including altered fire regimes, predation by feral cats, and grazing by feral herbivores. In addition, the loss of tree hollows due to frequent, intense fires may also be contributing to the decline of hollow-dependent mammals. We currently have little understanding of how the availability of tree hollows influences populations of hollow-dependent mammals in northern Australian savannas. Here, we test the hypothesis that the abundance of hollow-dependent mammals is higher in areas with a greater availability of tree hollows. We used camera-trap data from 82 sites across the savannas of Melville Island, the largest island in monsoonal northern Australia. Royle-Nichols abundanceinduced heterogeneity models were used to investigate the biophysical correlates of the abundance of three threatened mammals: northern brushtail possum (Trichosurus vulpecula arnhemensis), black-footed tree-rat (Mesembriomys gouldii), and brush-tailed rabbit-rat (Conilurus penicillatus). Our analyses included two variables that reflect the availability of tree hollows: the density of tree hollows, estimated from the ground, and the density of large eucalypt trees (Eucalyptus and Corymbia spp.). We found no evidence that the abundance of the three hollow-dependent mammals is positively associated with the availability of tree hollows on Melville Island. Despite their reliance on hollow-bearing trees for denning, the abundance of these mammals appears to be more strongly associated with other factors, such as the characteristics of the understory (i.e., shrub density), which affords protection from predators (including feral cats) and access to food resources. Future conservation management should aim to maintain a dense, diverse understory by managing fire and feral herbivores to facilitate the persistence of hollow-dependent mammals across northern Australia.

Keywords: cavity-bearing trees, eucalypts, fire management, land management, mammal decline, marsupials, tropical savanna, rodents 


\section{INTRODUCTION}

Australia has lost around $10 \%$ of its native terrestrial mammal species since the arrival of Europeans almost 250 years ago (Short and Hide, 2012; Woinarski et al., 2015). Introduced predators and/or habitat modification have been implicated in the majority of mammal declines and extinctions in Australia (Woinarski et al., 2014, 2019). Mammal declines and extinctions have been pervasive and severe among species with a body size in the so-called "critical weight range" (35-5,500 g; Cardillo and Bromham, 2001; Johnson and Isaac, 2009). Whereas most mammal extinctions occurred in central and southern Australia before the mid-20th Century, there are now severe declines occurring across the vast, uncleared savanna landscapes of northern Australia (Woinarski et al., 2010, 2011). Drivers of these declines have been difficult to identify, despite being one of Australia's most pressing biodiversity conservation challenges. However, a recent conceptual model postulates that the decline of native mammals across northern Australia reflects the interaction between habitat degradation (through overgrazing by feral herbivores and livestock and altered fire regimes) and predation processes (Stobo-Wilson et al., 2020a).

A disproportionate number of mammals in northern Australian savannas that have experienced severe declines are arboreal and semi-arboreal species that are reliant on tree-hollows for denning (Taylor et al., 2003; Woinarski et al., 2011). Once common across the savannas, hollow-dependent mammals have typically contracted to the higher rainfall, higher productivity parts of their ranges (Woinarski et al., 2014; von Takach et al., 2020), where large trees and hollows are most abundant (Woolley et al., 2018). Existing studies have noted the importance of eucalypts as den trees for northern Australian arboreal rodents and marsupials (Griffiths et al., 2001; Firth, 2003; Hohnen et al., 2015; Penton et al., 2020b; Stobo-Wilson et al., 2021). Stobo-Wilson et al. (2021) demonstrated den tree selection by the savanna glider (Petaurus ariel) differed based on hollow availability, highlighting the influence of hollow limitation in lower rainfall areas of the tropical savannas.

It has been suggested that an increase in the frequency of high-intensity fires in recent decades has reduced the abundance of large hollow-bearing trees in northern Australia's savannas (Woolley et al., 2018), which likely has had a negative impact on hollow-dependent mammals (Firth et al., 2010; Woinarski et al., 2011). Studies from temperate forests in Australia and overseas show a loss in hollow-bearing trees is typically associated with a decline in hollow-dependent fauna (Lindenmayer and Cunningham, 1997; Aitken and Martin, 2008; Cockle et al., 2010). As such, there may be a direct link between the decline of hollow-dependent mammals in northern Australian savannas and fire-driven loss of tree hollows.

To investigate whether the availability of tree hollows limits populations of hollow-dependent mammals in a high-rainfall tropical savanna, we analyzed camera-trap data on Melville Island, the largest island in monsoonal northern Australia (Figure 1). We hypothesized that the availability of tree hollows would be strongly correlated with the abundance of hollow-dependent mammals on Melville Island, while the attributes of the understory, such as shrub density, would be of secondary importance.

\section{MATERIALS AND METHODS}

\section{Study Site}

Melville Island is situated approximately $25 \mathrm{~km}$ off the central coast of northern Australia, and is Australia's second-largest island $\left(5,786 \mathrm{~km}^{2}\right)$ (Figure 1). Melville Island is the larger of the two main Tiwi Islands, a critical refuge for numerous mammal species that are in severe decline on the northern Australian mainland. However, recent evidence shows that mammals have declined on Melville Island over the last two decades (Davies et al., 2018). Although the declines have not progressed to the same extent as the mainland, the same processes are likely impacting the island populations (Stobo-Wilson et al., 2020a).

Melville Island experiences a tropical monsoonal climate, with over $90 \%$ of rainfall occurring in the wet season (Australian Bureau of Meteorology, 2020a). There is a substantial gradient in mean annual rainfall across the island, from 1,400 $\mathrm{mm}$ in the east to 2,000 $\mathrm{mm}$ in the north-west. Tropical savanna, dominated by tall eucalypts (predominantly Eucalyptus miniata, Eucalyptus tetrodonta, and Corymbia nesophila), covers $75 \%$ of the island (Woinarski et al., 2003). The understory is predominantly grassy, and shrub density is highly variable. Due to the high density of large trees, Melville Island generally supports a higher tree hollow densities than the adjacent mainland (Woolley et al., 2018; Penton et al., 2020a). Although hollow densities increase with mean annual rainfall across Melville Island, there is still substantial localized variability, driven by disturbance, such as tropical cyclones, fire, termite activity (Woolley et al., 2018). These forms of disturbance are particularly important drivers of hollow availability on Melville Island because the region is frequently exposed to severe tropical cyclones (Cook, 2001; Cook and Goyens, 2008), experiences very high fire frequencies (Richards et al., 2012), and has particularly high abundance and species richness of termites (Abensperg-Traun and Steven, 1997).

\section{Study Species}

We focused on three hollow-dependent, semi-arboreal mammals that once occurred across vast areas of northern Australia at the time of European arrival but are now in various stages of decline (Woinarski et al., 2011, 2014). All three are endemic to the tropical savannas. The northern brushtail possum (Trichosurus vulpecula arnhemensis) has declined severely (Stobo-Wilson et al., 2019), and remains abundant only in the highest-rainfall parts of its former range (von Takach et al., 2020), including the Tiwi Islands (Davies et al., 2018, 2021). The black-footed treerat (Mesembriomys gouldii) is one of Australia's largest rodents and has declined severely in both the Kimberley and mainland Northern Territory (Firth et al., 2010; von Takach et al., 2020), while the Melville Island subspecies (M. g. melvillensis) has also shown considerable decline (Davies et al., 2018). Finally, the brush-tailed rabbit-rat (Conilurus penicillatus) has experienced a very severe decline (Firth et al., 2010), and the Tiwi Islands subspecies (C. p. melibius) has displayed the same rapid pattern 


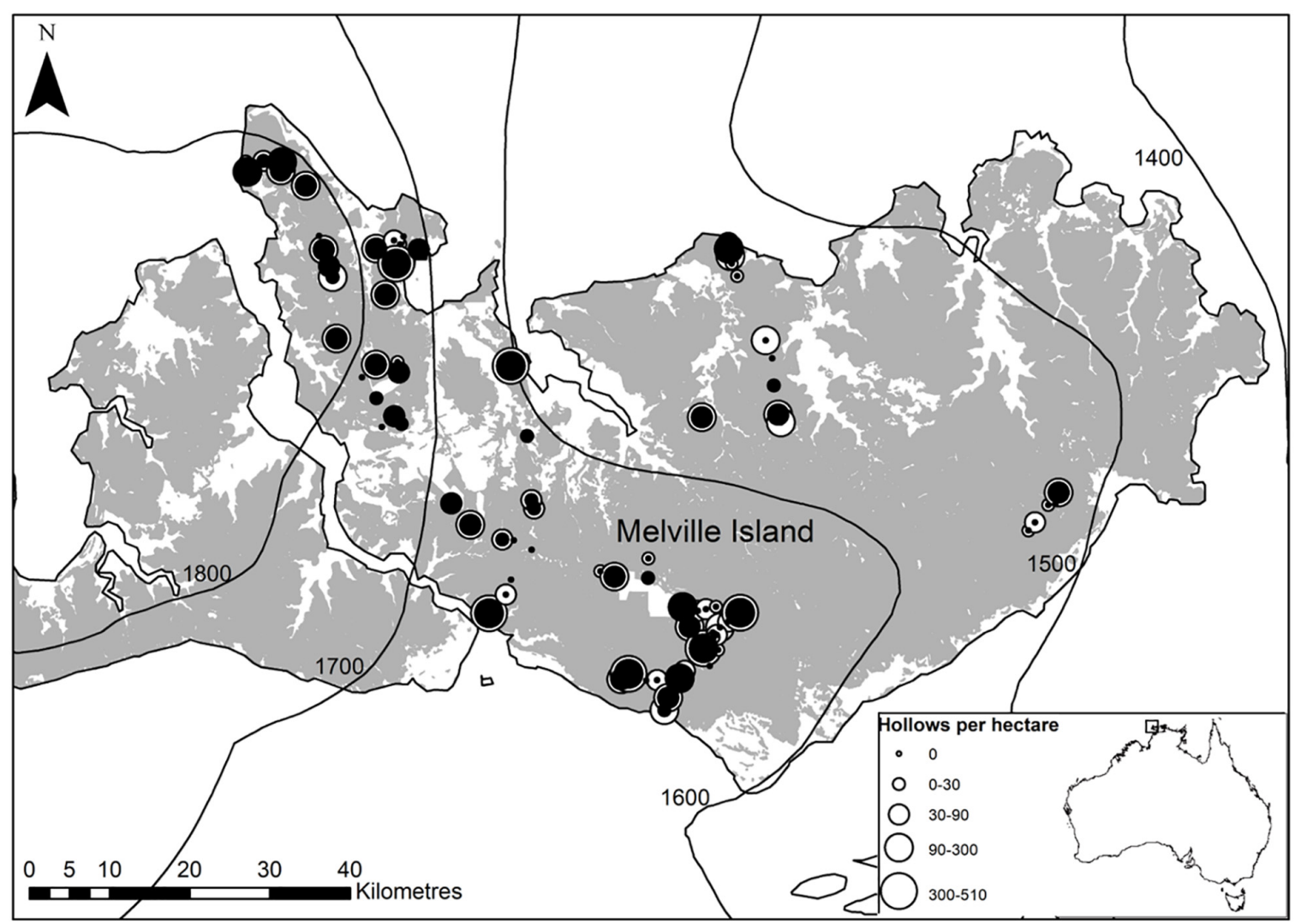

FIGURE 1 | Camera trap locations (Davies et al., 2018) and hollow surveyed sites (Penton et al., 2020a) across Melville Island, Northern Territory, Australia. Gray shading indicates eucalypt savanna and isohyets show the gradient in mean annual rainfall across the island. The diameter of the circles is proportional to the densities of hollows $\geq 5 \mathrm{~cm}$ entrance diameter in white and $\geq 10 \mathrm{~cm}$ entrance diameter in black at each site.

of decline on Melville Island (Davies et al., 2017). All three species (or subspecies in the case of the northern brushtail possum) are listed as Vulnerable under Australia's Environment Protection and Biodiversity Conservation Act (1999). Both rodents are listed as Vulnerable on the IUCN Red List (Burbidge and Woinarski, 2016; Woinarski and Burbidge, 2016).

Penton et al. (2020b) recently identified that the brushtailed rabbit-rat, black-footed tree-rat, and northern brushtail possum predominantly den in large hollows $(\geq 10 \mathrm{~cm}$ entrance diameter), which are generally found in large eucalypt trees [ $\geq 30 \mathrm{~cm}$ diameter at breast height $(\mathrm{DBH}), 1.3 \mathrm{~m}$ ]. Large hollows are relatively scarce in northern Australia's tropical savannas (estimated as only $10 \%$ of all hollows in the landscape), and trees with large hollows are particularly vulnerable to disturbance (Murphy and Legge, 2007; Woolley et al., 2018).

\section{Data Collection of Hollow-Dependent Mammal Abundance}

In 2015, camera trap surveys were conducted at 88 sites across the lowland savannas of Melville Island (Davies et al., 2017), which had been selected from previous surveys in 2000-2002 (see Firth et al., 2006a). Davies et al. (2017) selected the subset of sites located within savanna woodland, stratified by fire frequency and rainfall, separated by a minimum distance of $1 \mathrm{~km}$. Each site was surveyed with five horizontally facing motion-sensor cameras deployed in a square formation around a central camera, with $50 \mathrm{~m}$ between the central and outermost cameras. A bait station consisting of peanut butter, oats, and honey was placed $1.5 \mathrm{~m}$ from two of the five cameras, whereas the remaining three cameras at each site had a bait station placed $2.5 \mathrm{~m}$ from the camera (Gillespie et al., 2015). Vegetation within each camera's field of view was cleared to create a fire break and reduce the chance of false triggers, extending battery life. Of the five cameras deployed at each site, two were HC550 Hyperfire white-flash cameras, whereas the remaining three cameras PC800 Hyperfire Professional infra-red flash cameras (Reconyx, Inc., Holmen, WI, United States). Cameras could be triggered at any time of day and were set to a high sensitivity, with cameras programmed to take three images per trigger, with a 1-s interval between images. The cameras were deployed for at least 35 consecutive days (range 35-53 days).

This dataset has been analyzed previously by Davies et al. (2017, 2018), to investigate environmental correlates of the site-occupancy of mammals on Melville Island. However, due to very high site-occupancy rates for both the black-footed tree-rat and northern brushtail possum (Davies et al., 2018), occurring at most sites across the island, and gregarious 
social structure of the brush-tailed rabbit-rat (i.e., strong spatial clustering of populations; Firth et al., 2006b; Penton et al., 2020b), we considered that abundance was a more appropriate response variable (cf., site occupancy) to test our hypothesis. Hence, we used Royle-Nichols abundance-induced heterogeneity models, which assume that heterogeneity in detection frequency is indicative of variability in a species' abundance (Royle and Nichols, 2003).

\section{Tree Hollow Availability and Other Environmental Variables}

Davies et al. $(2017,2018)$ investigated a range of environmental correlates of site-occupancy of the brush-tailed rabbit-rat, blackfooted tree-rat, and northern brushtail possum. We used similar environmental variables, but to evaluate the influence of the availability of tree hollows and hollow-bearing trees on the abundance of hollow-dependent mammals, we revisited the mammal survey sites in 2017, 2 years after the original survey, and measured two additional variables: (1) hollow density and (2) density of large eucalypts (which are more likely to contain numerous hollows; Woolley et al., 2018; Table 1). Six of the sites surveyed in 2015 could not be resurveyed in 2017 and were excluded from the analysis, leaving 82 sites (Figure 1).

At each site, a random central reference point was selected following the plotless "point centered quarter" method (Krebs, 1999). To increase number of points sampled up to 12 trees (alive or dead) with a $\mathrm{DBH}$ of $\geq 15 \mathrm{~cm}$ closest to the central point, equally represented in each quadrant were selected for hollow surveys, which produced a total sample of 963 trees across 82 sites. The hollows in the selected trees were counted from the ground using binoculars. A hollow was defined as having an entrance diameter of $\geq 5 \mathrm{~cm}$. All ground-based surveys were performed by one individual (CP) and were conducted in good light and weather conditions for optimal visibility (e.g., no rain or mist). A minimum of 2 min was spent surveying each tree for hollows from all available vantage points. We recorded the total number of hollows in two entrance diameter classes $(5-10 \mathrm{~cm}$ and $\geq 10 \mathrm{~cm}$ ) for each tree. Due to the high frequency of termitaria blocking hollows $<10 \mathrm{~cm}$ entrance diameter, we calibrated 5$10 \mathrm{~cm}$ hollows before calculating total hollow counts $(\geq 5 \mathrm{~cm}$ and $\geq 10 \mathrm{~cm}$ entrance diameter) using a subset of trees that were double sampled with climbing surveys (Penton et al., 2020a).

We also recorded calculated large eucalypts (dead or alive) $\geq 30 \mathrm{~cm} \mathrm{DBH}$ at each site from the original tree dataset, which produced a sub-sample of 465 trees across the 82 sites. We calculated hollow and large eucalypt densities using the plotless "point-centered quarter" method where the area around the random point is divided into four quadrants, and the distance to the nearest tree is measured in each quadrant:

$$
\text { Estimated density }\left(h \mathrm{a}^{-1}\right)=\frac{4(4(n)-1)}{\pi \Sigma\left(r_{i j} 2\right)}
$$

Where $n$ is the number of samples and $r_{i j}$ is the distance $(\mathrm{m})$ from random point $i$ to the closest individual in quarter $j$ (Krebs, 1999; Jamali et al., 2020).

TABLE 1 | Description of the variables used in the analyses to assess the correlates of Melville Island arboreal mammal distribution in 2015.

Environmental Coding Measurement
variable

variable

Mean annual Continuous, centered, rainfall

Distance to watercourse and standardized

Continuous, centered, and standardized

Dingoes

$$
\text { Categorical }
$$

Large feral herbivores Categorical Feral cat activity

Continuous, centered, and standardized

Coarse woody debris

Shrub density

Large eucalypt density*

Hollow density* Continuous, centered, and standardized

Continuous, centered, and standardized

Continuous, centered,

Continuous, centered, and standardized
Mean annual rainfall (mm per annum) (Australian Bureau of Meteorology, 2020b)

The distance $(\mathrm{m})$ from each site to the closest watercourse derived from Geoscience Australia DEM SRTM 1 Second Hydrologically Enforced Map Presence/absence of dingoes. If a dingo was recorded once at the site, it was recorded as present Presence/absence of large feral herbivores. If a feral herbivore was recorded once at the site, it was recorded as present. Feral herbivores included water buffalo (Bubalus bubalis) and horse (Equus caballus)

As an index of feral cat activity. We used the predicted probability of detecting feral cats at each site, derived from spatially explicit generalized linear models (Murphy et al., 2010)

The number of times a site had been burned in the previous 5-year period (Lawes et al., 2015) immediately before the faunal survey (2015) from the Northern Australia Fire Information (NAFI) dataset (www.firenorth.org.au) and standardized

A count of the number of logs with a diameter of $>5 \mathrm{~cm}$ that crossed a $200 \mathrm{~m}$ long transect at each site

A count of the number of shrubs in a

$1 \mathrm{~m} \times 100 \mathrm{~m}$ quadrat at each site.

Shrubs were defined as anything

taller than $20 \mathrm{~cm}$ but shorter than

$1.3 \mathrm{~m}$ or taller than $1.3 \mathrm{~m}$ with a diameter at breast height of $<5 \mathrm{~cm}$.

Shrubs with multiple stems were counted as a single individual

Plotless PCQ method surveying eucalypts $\geq 30 \mathrm{~cm} \mathrm{DBH}$ (dead or alive) at each site

Plotless PCQ method surveying trees $\geq 15 \mathrm{~cm} \mathrm{DBH}$ for hollows 5-10 cm and $\geq 10 \mathrm{~cm}$ entrance diameter. Hollows 5-10 cm were calibrated before calculating total hollows $\geq 5 \mathrm{~cm}$ entrance diameter for the brush-tailed rabbit-rat and $\geq 10 \mathrm{~cm}$ entrance diameter for the larger bodied species at each site

*Between the faunal surveys and commencement of tree surveys Melville Island did not experience any major disturbances at the study sites (i.e., tropical cyclones or late dry season high-intensity wildfires). Six sites were burned between 31/07/2016 and 08/08/2016 (NAFI) just after the carbon abatement cut-off date, though this was not a high-intensity burn.

Penton et al. (2020b) found that den tree selection was significantly correlated with the presence of a large hollow (i.e., $\geq 10 \mathrm{~cm}$ entrance diameter) in that tree. They found that 
the brush-tailed rabbit-rat used tree hollows with an entrance diameter $\geq 5 \mathrm{~cm}$. Hence, for this species, we calculated hollow density using hollows with an entrance diameter $\geq 5 \mathrm{~cm}$ (Penton et al., 2020b). For the larger-bodied species (black-footed treerat and northern brushtail possum), which tend to use larger hollows, we calculated hollow density using only hollows with an entrance diameter $\geq 10 \mathrm{~cm}$.

\section{Data Analysis}

All analyses were undertaken in the statistical program $R(R$ Core Team, 2020). To examine the relationship between the abundance of three hollow-dependent species and our ten environmental variables (Table 1), we used Royle-Nichols abundance-induced heterogeneity models (Royle and Nichols, 2003) in the R package "unmarked" (Fiske and Chandler, 2011).

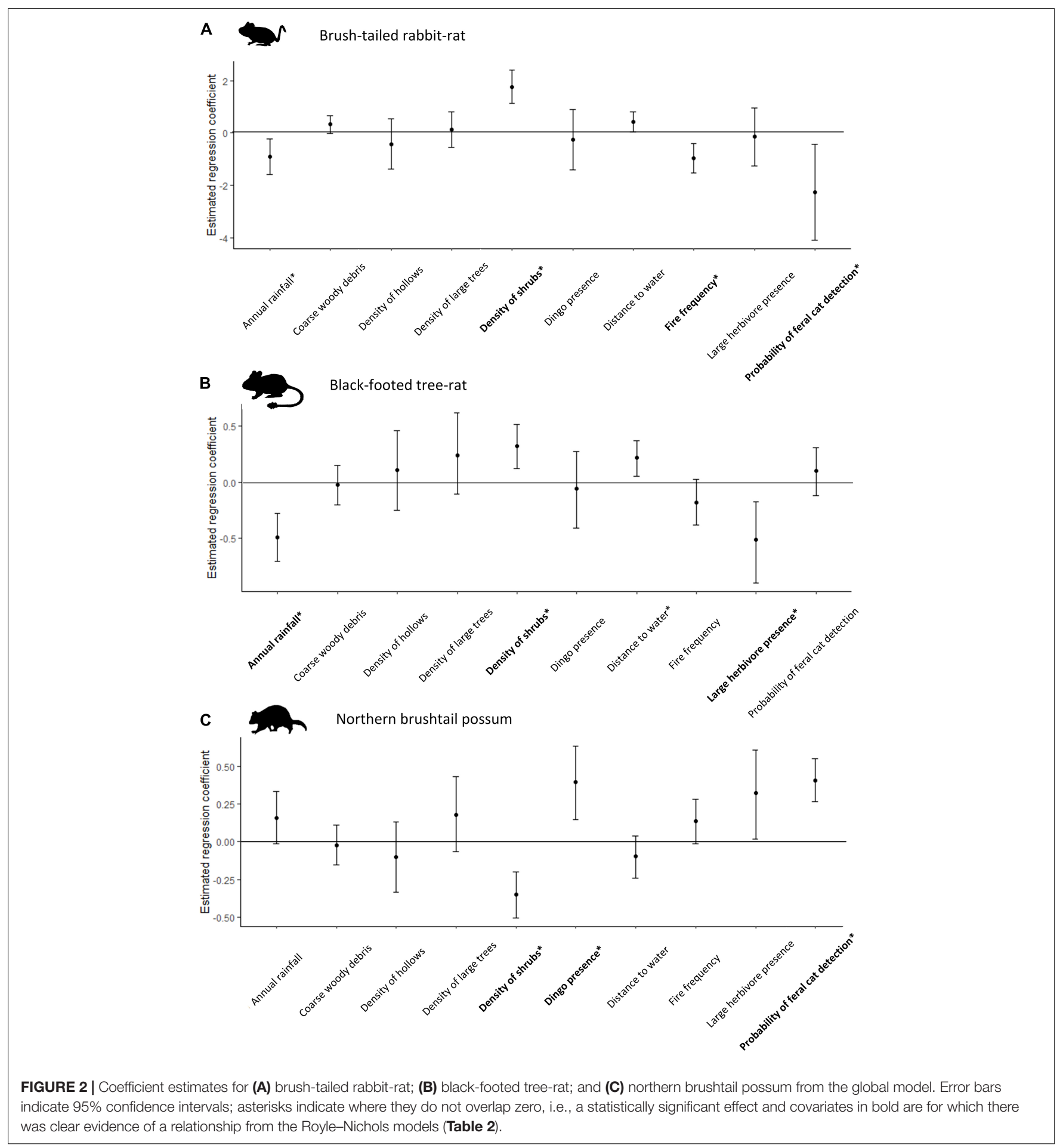


This model assumes that heterogeneity in detection frequency is indicative of variability in a species' abundance by assuming there is a constant probability of detecting each individual, and detections are independent. We created nightly detection histories for each of the three mammal species at each site by dividing the camera surveys into 24-h sampling occasions. Mammal detections were combined for all cameras at each site.

We developed a set of 1,024 candidate models to explain variation in the abundance of each mammal species. This represented all combinations of the ten environmental variables, with no interactions. Models were ranked and evaluated using Akaike's Information Criterion (AIC). All continuous environmental variables were log-transformed, then centered and standardized by deducting the mean and then dividing by twice the standard deviation (Gelman, 2008). We confirmed that there was not excessive collinearity among environmental variables by examining the variance inflation factor (VIF). Following Zuur et al. (2010), we used a conservative VIF threshold of 3; if a variable had VIF $>3$ we removed it. We further screened collinearity of variables with known associations (e.g., feral cat activity and fire frequency) with Pearson's correlation coefficient, $r$, to confirm all variables had a weak or negligible correlation (i.e., $r<0.45)$. We checked for spatial autocorrelation in the residuals of the global model by visually examining variograms of the model residuals and conducted a Moran's I test on the residuals of a linear regression global model with a response variable of total nights the species was recorded at a site in R package "ape" (Paradis and Schliep, 2019); brush-tailed rabbit-rat Moran's $I=0.08, p<0.001$; black-footed tree-rat Moran's $I=0.05, p=0.05$; northern brushtail possum Moran's $I=0.08, p=0.002$ indicating very weak spatial autocorrelation (Moran, 1950).

The abundance of arboreal mammals has been shown to have a "humped response" to hollow availability (Wormington et al., 2002). Thus, we initially considered a quadratic function (i.e., humped relationship) between the abundance of the three mammal species and each of hollow density and large eucalypt density. However, there was no evidence that quadratic relationships were more suitable than linear relationships. We also examined interactions between shrub density and large eucalypt density, the inclusion of the interaction terms did not substantially improve the best models (i.e., AIC reduced by $\geq 2$ ).

We created a global model, including all ten environmental variables, and plotted the standardized coefficients to evaluate the relative effect sizes of each variable (Figure 2). Variables that occurred in all of the well-supported models ( $\triangle \mathrm{AIC} \leq 2$; Table 2) were considered important environmental variables.

\section{RESULTS}

There was significant variability in the density of tree hollows and large eucalypts across Melville Island (Figure 1 and Table 3). Across all sites sampled, the mean density of hollows (entrance diameter $\geq 5 \mathrm{~cm})$ was $91 \mathrm{ha}^{-1}( \pm 12 \mathrm{SE})$, ranging from 0 to
$503 \mathrm{ha}^{-1}$. Of this, larger hollows (entrance diameter $\geq 10 \mathrm{~cm}$ ) contributed $37 \mathrm{ha}^{-1}$ ( $\pm 7 \mathrm{SE}$ ), ranging from 0 to $286 \mathrm{ha}^{-1}$. Larger hollows were present at only half of the sites surveyed. The mean density of large eucalypts was $66 \mathrm{ha}^{-1}( \pm 7 \mathrm{SE})$, ranging from 0 to 336 (Table 3).

We found no evidence that the abundance of the three hollow-dependent mammals was correlated with the density of tree hollows or large eucalypts. Neither hollow density nor large eucalypt density consistently appeared in well-supported models (Table 2).

The abundance of all three hollow-dependent mammals was strongly correlated with shrub density. This variable appeared in all well-supported models (Table 2). However, the direction of the relationship varied between species, being positive for the brush-tailed rabbit-rat and black-footed tree-rat, which were more abundant at shrubby sites (Figures 2A,B), but negative for the northern brushtail possum, which was less abundant at shrubby sites (Figure 2C).

Brush-tailed rabbit-rat abundance was strongly negatively correlated with cat activity and fire frequency (Table $\mathbf{2 A}$ and Figure 2A). Black-footed tree-rat abundance was negatively correlated with mean annual rainfall and feral herbivore presence (Table 2B and Figure 2B). Northern brushtail possum abundance was positively correlated with dingo presence and cat activity (Table 2C and Figure 2C).

Overall detectability from the best model ranged from 0.86 for the brush-tailed rabbit-rat to 0.99 for both the black-footed treerat and northern brushtail possum (Appendix 1).

\section{DISCUSSION}

We investigated the hypothesis that the availability of tree hollows strongly limits the abundance of hollow-dependent mammals. Despite significant variation in tree hollow availability across Melville Island, we found no evidence to support this hypothesis. We found that factors relating to the quality of the understory (i.e., shrub density, fire frequency, large herbivore presence) and predator assemblages (i.e., predicted cat activity, dingo presence) were stronger correlates of hollow-dependent mammal abundance on Melville Island, than were arboreal habitat features (i.e., hollow density, density of large eucalypts). Our study suggests that a disturbance-driven reduction in the availability of tree hollows has not played a significant role in driving the decline of hollow-dependent mammals on Melville Island, indicating that hollows are not limiting at this region. Rather, patterns of abundance are more strongly influenced by other factors associated with understory habitat quality and ground-based threats (i.e., shrub density and impacts of feral animals). This finding is consistent with recent studies of patterns of the abundance of small mammals across northern Australia more broadly (Davies et al., 2018; Legge et al., 2019; Stobo-Wilson et al., 2019, 2020a).

Although large hollows occur at varying densities across northern Australia's tropical savannas (Woolley et al., 2018), denning behaviors may compensate for variable availability of 
TABLE 2 | Model ranking table for the abundance three arboreal mammal species examined on Melville Island 2015: (A) brush-tailed rabbit-rat; (B) black-footed tree-rat; (C) northern brushtail possum.

\begin{tabular}{|c|c|c|c|c|c|c|c|c|c|c|c|c|c|}
\hline Response & $\begin{array}{l}\text { Mean annual } \\
\text { rainfall }\end{array}$ & $\begin{array}{l}\text { Distance to } \\
\text { water }\end{array}$ & $\begin{array}{c}\text { Dingo } \\
\text { presence/ } \\
\text { absence }\end{array}$ & $\begin{array}{l}\text { Feral cat } \\
\text { detection } \\
\text { probability }\end{array}$ & $\begin{array}{c}\text { Large } \\
\text { herbivore } \\
\text { presence/ } \\
\text { absence }\end{array}$ & Fire frequency & CWD & $\begin{array}{l}\text { Density of } \\
\text { shrubs }\end{array}$ & $\begin{array}{l}\text { Density of } \\
\text { large eucalypt } \\
\text { trees }\end{array}$ & $\begin{array}{l}\text { Hollow } \\
\text { density }\end{array}$ & $\Delta \mathrm{AIC}$ & wi & $\begin{array}{c}\text { Nagelkerke } \\
\text { R-squared } \\
\text { index }\end{array}$ \\
\hline \multirow{8}{*}{$\begin{array}{l}\text { (A) Brush-tailed } \\
\text { rabbit-rat Null } \\
\text { model; } \\
\text { AIC = 624.7, } \\
\text { logLik = -308.3 }\end{array}$} & $\bullet$ & • & & $\bullet$ & & $\bullet$ & - & $\bullet$ & & & 0.0 & 0.08 & 0.59 \\
\hline & - & & & - & & - & - & - & & & 0.7 & 0.13 & 0.59 \\
\hline & - & - & & - & & - & - & - & & - & 1.3 & 0.17 & 0.58 \\
\hline & & & & $\bullet$ & & - & - & - & & & 1.4 & 0.20 & 0.60 \\
\hline & • & - & & • & & • & & - & & & 1.5 & 0.24 & 0.57 \\
\hline & - & - & - & - & & - & - & - & & & 1.7 & 0.27 & 0.58 \\
\hline & • & • & & • & • & - & - & • & & & 1.8 & 0.30 & 0.60 \\
\hline & - & - & & - & & - & - & - & - & & 1.9 & 0.33 & 0.60 \\
\hline \multirow{12}{*}{$\begin{array}{l}\text { (B) Black-footed } \\
\text { tree-rat Null } \\
\text { model }=2134.3, \\
\text { logLik }=-1063.1\end{array}$} & - & - & & & - & - & & - & & & 0.0 & 0.03 & 0.29 \\
\hline & • & - & & & - & & & - & & & 0.4 & 0.06 & 0.27 \\
\hline & - & - & & & - & & & - & - & & 0.5 & 0.08 & 0.29 \\
\hline & - & - & & & - & - & & • & - & & 0.6 & 0.11 & 0.30 \\
\hline & - & • & & & • & & & • & & - & 0.7 & 0.13 & 0.29 \\
\hline & • & • & & • & • & • & & • & & & 1.0 & 0.15 & 0.30 \\
\hline & - & • & & & • & • & & • & & • & 1.3 & 0.17 & 0.30 \\
\hline & - & - & & & - & & & • & - & - & 1.5 & 0.18 & 0.30 \\
\hline & • & • & & • & • & - & & • & - & & 1.6 & 0.20 & 0.31 \\
\hline & - & • & • & & • & - & & • & & & 1.7 & 0.21 & 0.30 \\
\hline & - & - & & & - & - & - & - & & & 1.9 & 0.22 & 0.30 \\
\hline & - & & & & • & - & & - & & & 2.0 & 0.24 & 0.26 \\
\hline (C) Northern & - & & - & - & • & - & & - & & & 0.00 & 0.04 & 0.57 \\
\hline
\end{tabular}

\begin{tabular}{|c|c|c|c|c|c|c|c|c|}
\hline & & • & - & • & • & 0.2 & 0.07 & 0.56 \\
\hline & & • & - & • & • & 0.5 & 0.10 & 0.54 \\
\hline • & - & • & • & • & • & 0.8 & 0.12 & 0.57 \\
\hline • & & • & • & • & • & 1.0 & 0.15 & 0.57 \\
\hline & - & • & - & • & • & 1.0 & 0.18 & 0.56 \\
\hline • & & • & • & • & • & 1.0 & 0.19 & 0.55 \\
\hline
\end{tabular}




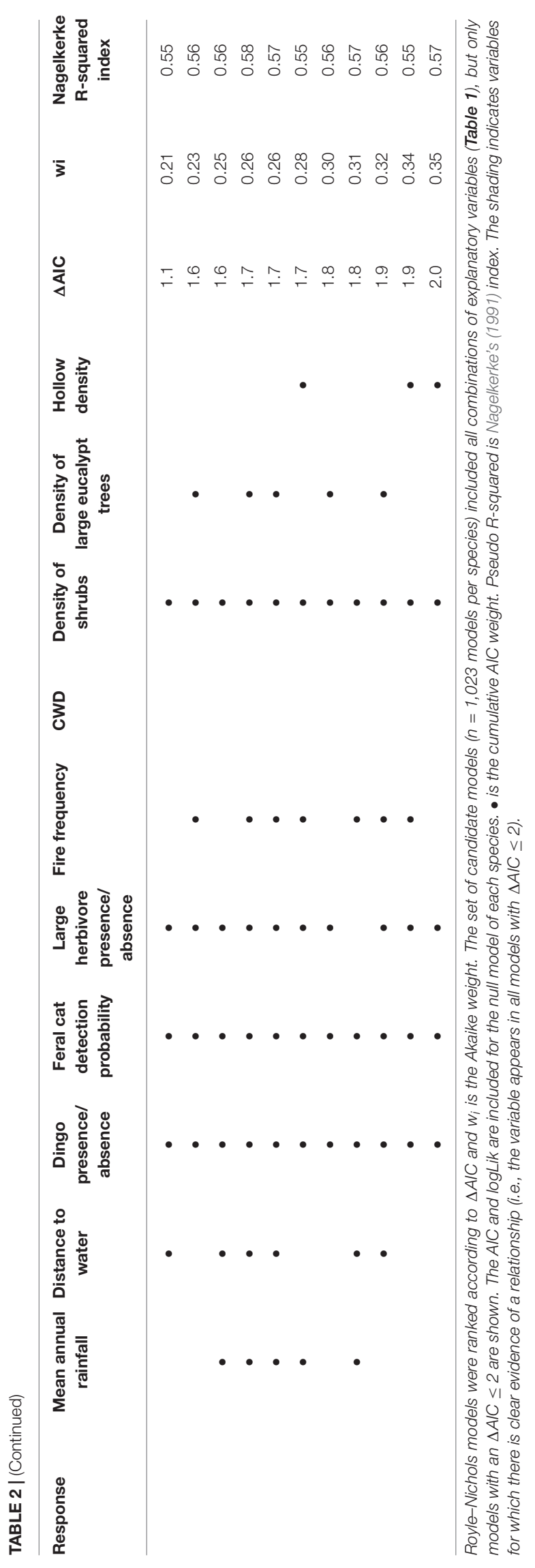

TABLE 3 | The density of hollows and large eucalypts across the 82 sites surveyed on Melville Island.

\begin{tabular}{|c|c|c|c|}
\hline Variables & Mean ( \pm SE) & $\begin{array}{l}\text { Median } \\
\text { (range) }\end{array}$ & $\begin{array}{c}\text { Proportion of } \\
\text { sites present } \\
\text { (\%) }\end{array}$ \\
\hline $\begin{array}{l}\geq 5 \mathrm{~cm} \text { hollow } \\
\text { density }\end{array}$ & $91( \pm 12) \mathrm{ha}^{-1}$ & $\begin{array}{c}55(0-503) \\
\mathrm{ha}^{-1}\end{array}$ & 85 \\
\hline $\begin{array}{l}\geq 10 \text { hollow } \\
\text { density }\end{array}$ & $37( \pm 7) \mathrm{ha}^{-1}$ & $3(0-286) \mathrm{ha}^{-1}$ & 50 \\
\hline $\begin{array}{l}\text { Large eucalypt } \\
\text { density }\end{array}$ & $66( \pm 7) \mathrm{ha}^{-1}$ & $\begin{array}{c}54(0-336) \\
\mathrm{ha}^{-1}\end{array}$ & 93 \\
\hline
\end{tabular}

The mean density, standard error, median and range of each variable. The percentage of total sites surveyed where hollows $(\geq 5 \mathrm{~cm}$ and $\geq 10 \mathrm{~cm})$ and large eucalypts were recorded present.

hollows in mesic savannas on Melville Island. The hollowdependent mammals we studied have been shown to use 26 dens in a fortnightly period, overlap in home range, and often use hollows of similar attributes (Penton et al., 2020b, 2021). Northern Australian arboreal mammals may also be more socially tolerant (Kerle, 1998), allowing them to adapt their denning behavior (e.g., increase their propensity to share dens) in areas where hollows are limiting (Banks et al., 2011). All three species use dens other than tree hollows, including hollow logs on the ground, the canopy of the arborescent monocotyledon Pandanus spiralis, and dreys (nests of dried leaves and twigs; Griffiths et al., 2001; Firth et al., 2006b; Penton et al., 2020b). Anecdotal evidence suggests that arboreal mammals were in higher abundance prior to European arrival across northern Australian savannas (Woinarski et al., 2011). In areas containing lower densities of hollow-bearing trees, it is likely that alternative den sites may have been used more frequently or at higher rates than recorded more recently. Current threats may be amplified where alternative den uptake is higher (i.e., in areas where hollow densities are lower) as there may be a higher risk of predation or exposure to disturbances such as high intensity fires when denning at or near ground level (Leahy et al., 2016). Therefore, hollow densities below a certain threshold may limit and impact the persistence of populations of hollow-dependent mammals.

The three hollow-dependent mammal species we studied demonstrate varying levels of arboreal behavior, spending time foraging and traveling across the savanna floor due to the open canopy structure of tropical savannas (Friend, 1987; Kerle, 1998; Griffiths et al., 2001; Firth et al., 2006b). The brush-tailed rabbitrat dens close to the ground or in hollow logs on the ground and spends much of its time foraging for grass seeds (Firth et al., 2005, 2006b; Penton et al., 2020b). Though the blackfooted tree-rat dens higher in the canopy (Penton et al., 2021), its reliance on fruiting shrubs, and its large home range (Friend, 1987; Pittman, 2003; Rankmore, 2006) suggests that this species frequently moves across the savanna floor. In comparison, the northern brushtail possum likely spends less time on the savanna floor as it has a smaller home range and does not exhibit large movements across the savanna (Kerle, 1998; Woinarski, 2004; Rankmore, 2006). Irrespective, all three species spend significant amounts of time on the ground foraging and moving across the 
savanna floor. The amount of time these species spend on the ground, and their reliance on understory and midstory resources, supports why we found the strongest correlates of abundance to be related to the quality of understory and predator assemblage, rather than the availability of tree hollows.

Despite having undergone a severe decline elsewhere in northern Australia (Woinarski et al., 2010; Stobo-Wilson et al., 2019), it appears that the northern brushtail possum is stable on Melville Island (Davies et al., 2018) even in disturbed areas (i.e., high cat activity and large herbivore presence). This may indicate that the northern brushtail possum is more resilient to these ground-based threats than the two rodent species examined in our study. The northern brushtail possum may spend a greater amount of time in the sub-canopy, as it preferentially feeds on flowers and fruits from Acacia difficilis, Grevillea pteridifolia, Acacia bivenosa, and Ficus spp. (Kerle and Burgman, 1984; Cruz et al., 2012). Historically, the distribution of the northern brushtail possum included areas of relatively low productivity. Although in more recent decades the contraction to higher rainfall areas of northern Australia and patchy distribution of northern brushtail possum populations has been attributed to a reliance on less disturbed areas that support dense and diverse foliage (Kerle and Burgman, 1984; Stobo-Wilson et al., 2019). Thus, while the decline of the northern brushtail possum on the mainland has been less severe than that of the rodents, it seems to be negatively affected by similar threats - most likely cat predation and reduction in habitat complexity - in the long-term.

The two rodent species in our study (black-footed treerat and brush-tailed rabbit-rat) may be particularly vulnerable across northern Australia because they are reliant on multiple vegetation strata, namely a shrubby understory and overstorey of hollow-bearing trees (Friend, 1987; Firth et al., 2006b; Penton et al., 2020b), and because they respond negatively to groundlayer disturbances including fire (Davies et al., 2017) and large herbivores. This habitat use will limit these species to areas with little disturbance to access adequate food resources and shelter. Simplification of understory habitat by overgrazing and frequent high-intensity fires likely reduces the availability of food resources while increasing the exposure of mammals to predation (Leahy et al., 2016; Legge et al., 2019). Native rodents may be more susceptible to feral cat predation as they represent the majority of native mammals killed Australia-wide, with this offtake strongly concentrated in northern Australia (Pearre and Maass, 1998; Murphy et al., 2019). Disturbances such as high-intensity fire and heavy grazing by feral herbivores can offer significant advantages to feral cats by simplifying the understory, increasing hunting efficiency (Davies et al., 2020; Stobo-Wilson et al., 2020a,b). Feral herbivores may also create "game trails," which facilitate the movement of cats and dingoes through the savanna (Leahy et al., 2016; McGregor et al., 2016; Davies et al., 2020). The question of why semi-arboreal and arboreal mammals have been disproportionally represented among declining mammals in northern Australia has not yet been resolved by this study. It is clear from our results that simply maintaining high densities of hollows in places such as Melville Island may not be sufficient to prevent further decline of hollow-dependent mammals.

\section{Implications for Future Research and Management}

Due to the higher densities of hollow-bearing trees on Melville Island compared to the mainland (Woolley et al., 2018), we are unable to speculate as to whether the depletion of tree hollows has contributed to the broad-scale decline of arboreal mammals in northern Australia. Frequent late dry-season fires have been shown to impact the density of suitable hollows for the threatened Gouldian finch (Erythrura gouldiae) in northern Australia (Radford et al., 2021). In habitats with low hollow densities, the frequent utilization of alternative dens (e.g., hollow logs, Pandanus spiralis) may expose individuals to greater predation risk and impact breeding success, particularly after fire (Leahy et al., 2016; Penton et al., 2020b). Future research should evaluate how mammal abundance varies with hollow availability across larger spatiotemporal scales to address whether frequent high-intensity fires have contributed to the dramatic decline of hollow-dependent arboreal species in northern Australia. Manipulative experiments using nest boxes could also provide insights into whether an increase in denning resources leads to an increase in native mammal abundance.

It is essential that the conservation management of native mammals in tropical savannas focuses on maintaining a complex and diverse understory. Studies on the northern Australian mainland have shown shrub density is strongly influenced by fire regimes, with frequent, high-intensity fires tending to reduce shrub density (Edwards et al., 2003, 2018; Russell-Smith et al., 2003). The impacts of which are also likely exacerbated by high feral herbivore densities (Legge et al., 2019). There needs to be a greater exploration of how frequent fires, even those of low intensity, influence vegetation structure and diversity, especially in relation to the shrub and grass layers, which provide critical shelter from predators and also provide food resources (e.g., fruits, flowers, and seeds; Bowman, 1988; Fensham, 1990; Paramjyothi et al., 2020). In the relatively intact savannas of northern Australia, such as Melville Island, management should aim to conserve hollow-bearing trees while retaining dense and complex under-and mid-story vegetation, which appears to be essential for the conservation of hollow-dependent arboreal mammal species.

\section{DATA AVAILABILITY STATEMENT}

The raw data supporting the conclusions of this article will be made available by the authors, without undue reservation.

\section{ETHICS STATEMENT}

The animal study was reviewed and approved by permission for animal use was authorized by the Charles Darwin University Animal Ethics Committee (A16002) and the Northern Territory Department of Flora and Fauna (Permit to Interfere with Protected Wildlife No. 58472). 


\section{AUTHOR CONTRIBUTIONS}

CP, BM, IR, L-AW, and HD conceived the idea for this chapter. TR, HD, and CP collected all the data for this chapter. CP completed all the analyses with support from $\mathrm{HD}$ and wrote the draft of the chapter. HD, L-AW, IR, and BM provided the editorial comments on the chapter. All authors contributed to the article and approved the submitted version.

\section{FUNDING}

This study was funded by the Australian Research Council (DE130100434, LP150100615, and FT170100004), Western Australian Department of Biodiversity, Conservation and

\section{REFERENCES}

Abensperg-Traun, M. A. X., and Steven, D. (1997). Short note: latitudinal gradients in the species richness of Australian termites (Isoptera). Austr. J. Ecol. 22, 471-477.

Aitken, K. E. H., and Martin, K. (2008). Resource selection plasticity and community responses to experimental reduction of a critical resource. Ecology 89, 971-980.

Australian Bureau of Meteorology (2020a). Annual Climate Summary for the Northern Territory. Available online at: http://www.bom.gov.au/climate/ current/annual/nt/summary.shtml (accessed January 14, 2021)

Australian Bureau of Meteorology (2020b). Northern Territory. Australia: BOM. Available online at: http://www.bom.gov.au/nt/observations/index.shtml?ref= hdr.2016-2.RLTS.T13211A22448856.en

Banks, S. C., Lindenmayer, D. B., McBurney, L., Blair, D., Knight, E. J., and Blyton, M. D. J. (2011). Kin selection in den sharing develops under limited availability of tree hollows for a forest marsupial. Proc. Biol. Sci. R. Soc. 278, 2768-2776. doi: $10.1098 /$ rspb.2010.2657

Bowman, D. M. J. S. (1988). "Stability amid turmoil: Towards an ecology of north Australian eucalypt forests," in Ecology of Australia's Wet Tropics. Proceedings of a symposium held at the University of Queensland, Brisbane, ed. R. L. Kitching 149-159.

Burbidge, A. A., and Woinarski, J. C. Z. (2016). Conilurus penicillatus. IUCN 2019. The IUCN Red List of Threatened Species. Version 2016:e.T5224A22450418. doi: 10.2305/IUCN.UK.2016-1.RLTS.T5224A22450418.en

Cardillo, M., and Bromham, L. (2001). Body size and risk of extinction in Australian mammals. Conserv. Biol. 15, 1435-1440. doi: 10.1046/j.1523-1739. 2001.00286.x

Cockle, K. L., Martin, K., and Drever, M. C. (2010). Supply of tree-holes limits nest density of cavity-nesting birds in primary and logged subtropical Atlantic forest. Biol. Conserv. 143, 2851-2857. doi: 10.1016/j.biocon.2010.08.002

Cook, G. D., and Goyens, C. M. A. C. (2008). The impact of wind on trees in Australian tropical savannas: lessons from cyclone monica. Austral Ecol. 33, 462-470. doi: 10.1111/j.1442-9993.2008.01901.x

Cook, N. A. (2001). Understanding hector: the dynamics of island thunderstorms. Monthly Weather Rev. 129, 1550-1563. doi: 10.1175/1520-04932001129<1550: $\mathrm{UHTDOI}<2.0 . \mathrm{CO} ; 2$

Cruz, J., Sutherland, D. R., Martin, G. R., and Leung, L. K.-P. (2012). Are smaller subspecies of common brushtail possums more omnivorous than larger ones? Austral Ecol. 37, 893-902. doi: 10.1111/j.1442-9993.2011.02346.x

Davies, H. F., Maier, S. W., and Murphy, B. P. (2020). Feral cats are more abundant under severe disturbance regimes in an Australian tropical savanna. Wildlife Res. 47, 624-632. doi: 10.1071/WR19198

Davies, H. F., McCarthy, M. A., Firth, R. S. C., Woinarski, J. C. Z., Gillespie, G. R., Andersen, A. N., et al. (2018). Declining populations in one of the last refuges for threatened mammal species in northern Australia. Austral Ecol. 43, 602-612. doi: $10.1111 /$ aec. 12596
Attractions, Plantation Management Partners, and Australian Government's National Environmental Science Program (funded through the Threatened Species Recovery Hub).

\section{ACKNOWLEDGMENTS}

We would like to thank the Tiwi Land Council and the Traditional Owners of the Tiwi Islands for their ongoing support of scientific research on their land, and TR for their on-ground assistance and sharing of knowledge, in particular Willie Rioli, Colin Kerinaiua, Willie Roberts, Brien Austral, Edward HenryWhiting, and the Tiwi College staff and students. We would also like to thank BB for their considerate attention, and the two reviewers whose comments improved this manuscript.

Davies, H. F., Rangers, T. L., Nicholson, E., and Murphy, B. P. (2021). Northern brown bandicoot (Isoodon macrourus) and common brushtail possum (Trichosurus vulpecula) density on the Tiwi Islands; insights and implications. Pacific Conserv. Biol. doi: 10.1071/PC2 1020

Davies, H. F. G., Mccarthy, M. A., Firth, R. S. C., Woinarski, J. C. Z., Gillespie, G. R., Andersen, A. N., et al. (2017). Top-down control of species distributions: feral cats driving the regional extinction of a threatened rodent in northern Australia. Div. Distr. 23, 272-283. doi: 10.1111/ddi.12522

Edwards, A., Kennett, R., Price, O., Russell-Smith, J., Spiers, G., and Woinarski, J. (2003). Monitoring the impacts of fire regimes on vegetation in northern Australia: an example from kakadu national park. Int. J. Wildland Fire 12, 427-440. doi: 10.1071/wf03031

Edwards, A. C., Russell-Smith, J., and Maier, S. W. (2018). A comparison and validation of satellite-derived fire severity mapping techniques in fire prone north Australian savannas: extreme fires and tree stem mortality. Remote Sensing Environ. 206, 287-299. doi: 10.1016/j.rse.2017. 12.038

Fensham, R. J. (1990). Interactive effects of fire frequency and site factors in tropical eucalyptus forest. Austr. J. Ecol. 15, 255-266. doi: 10.1111/j.1442-9993.1990. tb01029.x

Firth, R. S. C. (2003). “Activity range and den trees of the Brush-tailed Rabbit-rat on Cobourg Peninsula," in Rats, Mice and People: Rodent Biology and Management eds G. Singleton, L. A. Hinds, C. J. Krebs and D. Spratt (Australia: Australian Centre for Agricultural Research), 99-102.

Firth, R. S. C., Brook, B. W., Woinarski, J. C. Z., and Fordham, D. A. (2010). Decline and likely extinction of a northern Australian native rodent, the brush-tailed rabbit-rat Conilurus penicillatus. Biol. Conserv. 143, 1193-1201. doi: 10.1016/j. biocon.2010.02.027

Firth, R. S. C., Jefferys, E., Woinarski, J. C. Z., and Noske, R. A. (2005). The diet of the brush-tailed rabbit-rat (Conilurus penicillatus) from the monsoonal tropics of the Northern Territory, Australia. Wildlife Res. 32, 517-523. doi: 10.1071/WR04127

Firth, R. S. C., Woinarski, J. C. Z., Brennan, K. G., and Hempel, C. (2006a). Environmental relationships of the brush-tailed rabbit-rat, Conilurus penicillatus, and other small mammals on the Tiwi Islands, Northern Australia. J. Biogeogr. 33, 1820-1837. doi: 10.1111/j.1365-2699.2006.0 1543.x

Firth, R. S. C., Woinarski, J. C. Z., and Noske, R. A. (2006b). Home range and den characteristics of the brush-tailed rabbit-rat (Conilurus penicillatus) in the monsoonal tropics of the Northern Territory, Australia. Wildlife Res. 33:397. doi: 10.1071/wr05057

Fiske, I., and Chandler, R. (2011). Unmarked: an R package for fiting hierarchical models of wildlife occurrence and abundance. J. Statist. Softw. 43, 1-23.

Friend, G. R. (1987). Population ecology of Mesembriomys gouldii (rodentia: muridae) in the wet-dry tropics of the northern territory. Austr. Wildlife Res. 14, 293-303. 
Gelman, A. (2008). Scaling regression unputs by dividing by two standard deviations. Statist. Med. 27, 2865-2873. doi: 10.1002/sim.3107

Gillespie, G. R., Brennan, K., Gentles, T., Hill, B., Low Choy, J., Mahney, T., et al. (2015). A guide for the Use of Remote Cameras for Wildlife Survey in Northern Australia. Darwin: National Environmental Research Program, Northern Australia Hub, Charles Darwin University.

Griffiths, A. D., Koenig, J., Carrol, F., and Price, O. F. (2001). Activity area and day-time tree use of the black-footed tree-rat Mesembriomys gouldii. Austr. Mammal. 23, 181-184. doi: 10.1071/AM01181

Hohnen, R., Tuft, K. D., Legge, S. M., Radford, I. J., Carver, S., and Johnson, C. N. (2015). Post-fire habitat use of the golden-backed tree-rat (Mesembriomys macrurus) in the northwest Kimberley, Western Australia. Austral. Ecol. 40, 941-952. doi: 10.1111/aec.12278

Jamali, H., Ebrahimi, A., Ardestani, E. G., and Pordel, F. (2020). Evaluation of plotless desnity estimators in different plant density intensities and distribution patterns. Global Ecol. Consev. 23:e01114. doi: 10.1016/j.gecco.2020.e01114

Johnson, C. N., and Isaac, J. L. (2009). Body mass and extinction risk in Australian marsupials: the "critical weight range" revisited. Austral Ecol. 34, 35-40. doi: 10.1111/j.1442-9993.2008.01878.x

Kerle, J. A. (1998). The population dynamics of a tropical possum, Trichosurus vulpecula arnhemensis collett. Wildlife Res. 25, 171-181. doi: 10.1071/WR96113

Kerle, J. A., and Burgman, M. A. (1984). Some aspects of the ecology of the mammal fauna of the Jabiluka area, Northern Territory. Wildlife Res. 11, 207-222. doi: 10.1071/WR9840207

Krebs, C. J. (1999). Ecological Methodology, 2nd Edn. Menlo Park, CA: Benjamin/Cummings.

Lawes, M. J., Murphy, B. P., Fisher, A., Woinarski, J. C., Edwards, A., and RussellSmith, J. (2015). Small mammals decline with increasing fire extent in northern Australia: evidence from lon-term monitoring in kakadu national park. Int. J. Wild. Fire 24:712.

Leahy, L., Legge, S. M., Tuft, K., Mcgregor, H. W., Barmuta, L. A., Jones, M. E., et al. (2016). Amplified predation after fire suppresses rodent populations in Australia's tropical savannas. Wildlife Res. 42, 705-716.

Legge, S., Smith, J. G., James, A., Tuft, K. D., Webb, T., and Woinarski, J. C. Z. (2019). Interactions among threats affect conservation management outcomes: livestock grazing removes the benefits of fire management for small mammals in Australian tropical savannas. Conserv. Sci. Practice 1, 1-13. doi: 10.1111/ csp 2.52

Lindenmayer, D. B., and Cunningham, R. B. (1997). Patterns of co-occurrence among arboreal marsupials in the forests of central Victoria, southeastern Australia. Austral Ecol. 22, 340-346. doi: 10.1111/j.1442-9993.1997. tb00680.x

McGregor, H. W., Cliff, H. B., and Kanowski, J. (2016). Habitat preference for fire scars by feral cats in Cape york peninsula, Australia. Wildlife Res. 43, 623-633. doi: 10.1071/WR16058

Moran, P. A. (1950). A test for the serial independence of residuals. Biometrika 37, 178-181. doi: 10.1093/biomet/37.1-2.178

Murphy, B. P., Paron, P., Prior, L. D., Boggs, G. S., Franklin, D. C., and Bowman, D. M. (2010). Using generalized autoregressive error models to understand firevegetation-soil feedbacks in a mulgaspinifex landscape mosaic. J. Biogeogr. 37 2169-2182.

Murphy, B. P., Woolley, L.-A., Geyle, H. M., Legge, S. M., Palmer, R., Dickman, C. R., et al. (2019). Introduced cats (Felis catus) eating a continental fauna: the number of mammals killed in Australia. Biol. Consver. 237, 28-40. doi: 10.1016/j.biocon.2019.06.013

Murphy, S., and Legge, S. (2007). The gradual loss and episodic creation of palm cockatoo (Probosciger aterrimus) nest-trees in a fire- and cyclone-prone habitat. Етu 107, 1-6. doi: 10.1071/MU06012

Nagelkerke, N. J. D. (1991). A note on a general definition of the coefficient of determination. Biometrika 78, 691-692.

Paradis, E., and Schliep, K. (2019). ape 5.0: an environment for modern phylogenetics and evolutionary analyses in R. Bioinfomatics 35, 526-528.

Paramjyothi, H., Murphy, B. P., Lawes, M. J., Rossiter-Rachor, N. A., and Richards, A. E. (2020). Does rapid utilization of elevated nutrient availability allow eucalypts to dominate in the tropical savannas of Australia? Ecol. Evolu. 10, 4021-4030. doi: 10.1002/ece3.6168

Pearre, J. R. S., and Maass, R. (1998). Trends in the prey size-based trophic niches of feral and house cats Felis catus L. Mammal. Rev. 28, 125-139.
Penton, C. E., Radford, I. J., Woolley, L. A., von Takach, B., and Murphy, B. P. (2021). Unexpected overlapping use of tree hollows by birds, reptiles and declining mammals in an Australian tropical savanna. Bio. Conservation 30, 2977-3001. doi: 10.1007/s10531-021-02231-6

Penton, C. E., Woolley, L., Radford, I. J., and Murphy, B. P. (2020a). Blocked-off: termitaria cause the overestimation of tree hollow availability by ground-based surveys in northern Australia. Forest Ecol. Manage. 458:117707. doi: 10.1016/j. foreco.2019.117707

Penton, C. E., Woolley, L., Radford, I. J., and Murphy, B. P. (2020b). Overlapping den tree selection by three declining arboreal mammal species in an Australian tropical savanna. J. Mammal. 101, 1165-1176. doi: 10.1093/jmammal/gyaa074

Pittman, G. W. (2003). Ocurrence and Use of Tree Hollows by Mammals in Fragmented and Continuous Savanna Woodland in Northern Australia (Honours Thesis). Darwin, NT: Charles Darwin University.

R Core Team (2020). R: A Language and Environment for Statistical Computing. Vienna: R Foundation for Statistical Computing.

Radford, I. J., Oliveira, S. L. J., Byrne, B., and Woolley, L.-A. (2021). Tree hollow densities reduced by frequent late dry-season wildfire in threatened Gouldian finch (Erythrura gouldiae) breeding habitat. Wildlife Res. 48, 511-520. doi: 10. 1071/WR20108

Rankmore, B. R. (2006). Impacts of Habitat Fragmentation on the Vertebrate Fauna of the Tropical Savannas of Northern Australia; With Special Reference to Medium-Sized Mammals (Ph. D, Thesis). Darwin, NT: Charles Darwin University.

Richards, A., Andersen, A., Schatz, J., Eager, R., Dawes, T., Hadden, K., et al. (2012). Savanna burning, greenhouse gas emissions and indigenous livelihoods: introducing the tiwi carbon study. Austral Ecol. 37, 712-723. doi: 10.1111/j. 1442-9993.2012.02395.x

Royle, J. A., and Nichols, J. (2003). Estimating abundance from repeated presenceabsence. Ecology 84, 777-790.

Russell-Smith, J., Yates, C., Edwards, A., Allan, G. E., Cook, G. D., Cooke, P., et al. (2003). Contemporary fire regimes of northern Australia, 1997-2001: change since aboriginal occupancy, challenges for sustainable management. Int. J. Wildland Fire 12:283. doi: 10.1071/WF03015

Short, J., and Hide, A. (2012). Distribution and status of the red-tailed phascogale (Phascogale calura). Austr. Mammal. 34, 88-99. doi: 10.1071/AM11017

Stobo-Wilson, A. M., Cremona, T., Murphy, B. P., and Carthew, S. M. (2021). Resource availability drives variation in a marsupial glider's home-range size. J. Zool. doi: 10.1111/jzo.12906

Stobo-Wilson, A. M., Murphy, B. P., Cremona, T., and Carthew, S. M. (2019). Contrasting patterns of decline in two arboreal marsupials from Northern Australia. Bio. Conserv. 28, 2951-2965. doi: 10.1007/s10531-019-01807-7

Stobo-Wilson, A. M., Stokeld, D., Einoder, L. D., Davies, H. F., Fisher A., Hill, B. M., et al. (2020a). Bottom-up and top-down processes influence contemporary patterns of mammal species richness in Australia's monsoonal tropics. Biol. Conserv. 247:108638. doi: 10.1016/j.biocon.2020.1 08638

Stobo-Wilson, A. M., Stokeld, D., Einoder, L. D., Davies, H. F., Fisher, A., Hill, B. M., et al. (2020b). Habitat structural complexity explains patterns of feral cat and dingo occurrence in monsoonal Australia. Div. Distr. 26, 832-842. doi: 10.1111/ddi.13065

Taylor, R., Woinarski, J., and Chatto, R. (2003). Hollow use by vertebrates in the top end of the northern territory. Austr. Zool. 32, 462-476.

von Takach, B., Scheele, B. C., Moore, H., Murphy, B. P., and Banks, S. C. (2020). Patterns of niche contraction identify vital refuge areas for declining mammals. Div. Distr. 26, 1467-1482. doi: 10.1111/ddi.13145

Woinarski, J. C. Z. (2004). "In a land with few possums, even the common are rare: ecology, conservation and management of possums in the Northern Territory," in Biology of Australian Possums and Gliders, ed. R. L. Goldingay (Sydney: Surrey Beatty \& Sons), 51-62.

Woinarski, J. C. Z., Armstrong, M., Brennan, K. G., Fisher, A., Griffiths, A. D., Hill, B. M., et al. (2010). Monitoring indicates rapid and severe decline of native small mammals in kakadu national park, northern Australia. Wildlife Res. 37, 116-126. doi: 10.1071/WR09125

Woinarski, J. C. Z., Braby, M. F., Burbidge, A. A., Coates, D., Garnett, S. T., Fensham, R. J., et al. (2019). Reading the black book: the number, timing, distribution and causes of listed extinctions in Australia. Biol. Conserv. 239:108261. doi: 10.1016/j.biocon.2019.108261 
Woinarski, J. C. Z, and Burbidge, A. A. (2016). Mesembriomys gouldii gouldii. The IUCN. The IUCN Red List of Threatened Species 2016. Version 2016:e.T13211A22448856. doi: 10.2305/IUCN.UK

Woinarski, J. C. Z., Burbidge, A., and Harrison, P. (2014). Action Plan for Australian Mammals 2012. Melbourne: CSIRO Publishing.

Woinarski, J. C. Z., Burbidge, A. A., and Harrison, P. L. (2015). Ongoing unraveling of a continental fauna: decline and extinction of Australian mammals since European settlement. Proc. Natl. Acad. Sci. U.S.A. 112, 4531-4540. doi: 10.1073/ pnas. 1417301112

Woinarski, J. C. Z., Hadden, K., Hicks, J., McLeod, D., Brennan, K. G., Cowie, I., et al. (2003). Biodiversity Conservation on the Tiwi Islands, Northern Territory: Part 1. Environments and plants. Darwin: Tiwi Land Council.

Woinarski, J. C. Z., Legge, S., Fitzsimons, J. A., Traill, B. J., Burbidge, A. A., Fisher, A., et al. (2011). The disappearing mammal fauna of northern Australia: context, cause, and response. Conserv. Lett. 4, 192-201. doi: 10.1111/j.1755263X.2011.00164.x

Woolley, L. A., Murphy, B. P., Radford, I. J., Westaway, J., and Woinarski, J. C. Z. (2018). Cyclones, fire, and termites: the drivers of tree hollow abundance in northern Australia’s mesic tropical savanna. Forest Ecol. Manage. 419, 146-159. doi: 10.1016/j.foreco.2018.03.034

Wormington, K. R., Lamb, D., Mccallum, H. I., and Moloney, D. J. (2002). Habitat requirements for the conservation of arboreal marsupials in dry sclerophyll forest in south-east Queensland, Australia. Forest Sci. 48, 217-227.
Zuur, A. F., Ieno, E. N., and Elphick, C. S. (2010). A protocol for data exploration to avoid common statistical problems. Methods Ecol. Evolu. 1, 3-14. doi: 10.1111/ j.2041-210X.2009.00001.x

Conflict of Interest: TR was employed by company Tiwi Resources Pty., Ltd., Casuarina, NT, Australia.

The remaining authors declare that the research was conducted in the absence of any commercial or financial relationships that could be construed as a potential conflict of interest.

Publisher's Note: All claims expressed in this article are solely those of the authors and do not necessarily represent those of their affiliated organizations, or those of the publisher, the editors and the reviewers. Any product that may be evaluated in this article, or claim that may be made by its manufacturer, is not guaranteed or endorsed by the publisher.

Copyright $\odot 2021$ Penton, Davies, Radford, Woolley, Rangers and Murphy. This is an open-access article distributed under the terms of the Creative Commons Attribution License (CC BY). The use, distribution or reproduction in other forums is permitted, provided the original author(s) and the copyright owner(s) are credited and that the original publication in this journal is cited, in accordance with accepted academic practice. No use, distribution or reproduction is permitted which does not comply with these terms. 


\section{APPENDIX}

Appendix 1 | Comparison of the nightly probability of detection and the overall probability of detection (over 36-53 nights) for the null model (where relative abundance and detectability parameters are assumed to be constant across all survey sites) and the most parsimonious Royle-Nichols occupancy model.

\begin{tabular}{|c|c|c|c|}
\hline Species & Model & $\begin{array}{c}\text { Night } \\
\text { detection } \\
\text { probability }(\mathrm{P}) \\
( \pm \mathrm{SE})\end{array}$ & $\begin{array}{c}\text { Overall } \\
\text { detection } \\
\text { probability }\end{array}$ \\
\hline \multirow[t]{2}{*}{ Brush-tailed rabbit-rat } & Null model & $0.10( \pm 0.02)$ & 0.99 \\
\hline & Best model & $0.04( \pm 0.04)$ & 0.86 \\
\hline Black-footed tree-rat & Null model & $0.11( \pm 0.01)$ & 0.99 \\
\hline & Best model & $0.10( \pm 0.01)$ & 0.99 \\
\hline
\end{tabular}

